\title{
The Misapplication of Democracy and the Plight of the Individual in the Drama of Henrik Ibsen
}

\author{
Innocent Ettia Meh \\ Higher Teacher Training College, Ngaoundere University, Bertoua, Cameroon
}

Email address:

mehisco@yahoo.com

\section{To cite this article:}

Innocent Ettia Meh. The Misapplication of Democracy and the Plight of the Individual in the Drama of Henrik Ibsen. International Journal of Literature and Arts. Vol. 9, No. 1, 2021, pp. 9-14. doi: 10.11648/j.ijla.20210901.12

Received: December 23, 2020; Accepted: January 14, 2021; Published: January 22, 2021

\begin{abstract}
Let me begin by stating the obvious. It is now common knowledge in Henrik Ibsen's scholarship that the Norwegian playwright had a very uneasy relationship with politicians. The dramatist took delight in satirizing the pomposity and hypocritical practices of politicians and other public officials through the use of a flowery rhetorical style characteristic of platform politicians. A close reading of critical writings on Ibsen's major plays that have a political agenda reveals that most of the reputed commentators conclude that the author directs his criticism against the democratic form of government. Some of the critics are even of the opinion that Ibsen in his works is in favour of aristocracy as an alternative to democracy. What is however intriguing about the claims of these critics is that they do not actually take up time to define what democracy as a form of government is all about before illustrating how the dramatist writes against it in his plays. The central concern of this paper therefore, is to demonstrate from a new historicist standpoint that Ibsen in his drama does not completely condemns democracy as a form of government except when it comes to the application of some democratic principles which are hostile to the welfare of the individual.
\end{abstract}

Keywords: Misapplication, Democracy, The Individual, Ibsen

\section{Introduction}

According to New Historicists, works of art can be read as subversive discourses offering a critique of the prevailing socio-political and economic ideologies of the society in which they were written. In his essay titled the "The Poetics of Culture,"as quoted by Kreiswirth M. and Michael Groden, [1], Louis Montrose posits that New Historicism "is concerned with how a literary work offers a genuinely radical critique of authority, or how a text articulates views that threaten political orthodoxy." In other words, "a willingness to explore the political potential of writing is a distinguishing mark of new historicism." (535)

The quickening force behind the writing of this paper is to critically examine how conservative middle class politicians misapply some democratic principles that inhibit the progress and self-fulfillment of the individual. This study will focus on Ibsen's A Doll's House, [2] The Pillars of the Society, [3] An Enemy of the People [4] and Rosmersholm. [5] Before proceeding with our discussion, it important to determine however briefly, what democracy is all about. This will enable us to clearly fathom the extent to which the plays are subversive discourses against the political practices of the period and society where they were written. According to Cherif Bassiouni et al [6].

Democracy aims essentially to preserve and promote the diginity and fundamental rights of the individual, to achieve social justice, foster economic and social development of the community...

The online Wikipedia dictionary defines democracy as a political form of government where governing powers emanates from the people either by means of elected representatives or through a referendum. This means that in a democratic system, government is the servant of the people and is answerable to them since the power it wields comes directly from the people. This goes to corroborate Abraham Lincoln's definition which states that democracy is government of the people, by the people and for the people. In order to be labeled a modern democracy, a country needs to fulfill some basic requirements and these requirements need not only be written down in the constitution but must be kept up or implemented in everyday life by the governing 
authorities and politicians. Some of the basic principles of democracy include: the guarantee of basic human rights, majority rule, and separation of powers, that is, the executive, parliament and the judiciary. A democratic country must also promote freedom of speech and opinion, equality of all citizens before the law, religious liberty, general and equal right to vote in competitive free, transparent and fair elections. Individual freedom should be guaranteed so that citizens can vote in their personal interest. There should also, and above all, be good governance. By good governance, we mean, focus should be placed on the general welfare of the entire community and there should as well be absence of corruption which is one of the canker worm that has eaten deep into the fabrics of modern society. Albert Sama [7] in his book entitled Nation Building, Governance and Human Rights intimates that, "for governance to have positive results, it must have the following traits; participation, rule of law, transparency, equity, inclusiveness, consensus oriented, responsiveness, efficiency and accountability (92). Sama further notes that, "the test of good governance in a country is made manifest through its results...the vibrancy of the civil society, and job creation by both the state and individuals.

Critics who argue that Ibsen is an anti-democrat par excellence may certainly have to convince us that the playwright in his works is against all the lofty principles of democracy highlighted above. Put differently, critics who take Ibsen for a complete anti-democrat do not adequately substantiate or convincingly prove their point. For example, Mordecia Roshwald [8] has noted that "Ibsen's attack on democracy is clearly exaggerated and vulnerable."(227). In the words of Chesterton G k, [9] "the playwright made no disguise for his passionate hatred of democracy." (222). In his article titled "Henrik Ibsen: Anti-Democrat and Individualist," K. Balzersen [10] opines that, "the primary anti-democratic contribution of Ibsen is arguably An Enemy of the People" (5). Balzersen goes further to note that Ibsen in the play advocates aristocracy in the place of democracy. Like Balzersen, George Bernard Shaw [11] in The Quintessence of Ibsenism concludes that the playwright in $\mathrm{An}$ Enemy of the People is against democracy. Shaw notes that in the past, men used to submit "to kings and consoled themselves by making it an act of faith that the king was always right...in the same way, we who have to submit to the majorities make it blasphemy against democracy to deny that the majority is always right, although as Ibsen says, it is a lie." To Martin Esslin, (12), Ibsen in An Enemy of the People advocates aristocracy as an alternative to democracy. Didachos Afuh Mbeng (13) argues that Ibsen in the plays under study is an ambivalent writer who presents both the democratic and aristocratic forms of government without necessarily being in support of any of them. Without any intention of wanting to condemn all the aforementioned critical views, this study seeks to demonstrate that the playwright was only a partial anti-democrat especially as far as individual liberty and the democratic principle of majority rule were concerned. The dramatist was concerned more with showing how middle class conservative politicians misused democracy for their personal and political aggrandizement. A critical reading of his plays reveal that democracy was a paper functioning mechanism in the middle class society of his day. In the words of Harold Bloom [14], Ibsen was writing at a time "when society professing liberalism in name only, distanced itself from the ideals of liberty and equity (28).

\section{Political Conservatism, the Majority and the Individual}

To begin with, Dr Stockman, the protagonist of An Enemy of the People is a victim of the hypocritical practices of selfseeking conservative politicians. The physician discovers that the town's water system managed by his brother, Peter Stockman (city mayor) is polluted. It is with excitement that he goes to his brother, who is the leading politician of the town to discuss the matter with him so that something can be done urgently to rescue the situation before an epidemic breaks out as a result of the poor sanitary conditions. But Peter Stockman who thinks only in monetary terms estimates that it will be too costly for him to undertake any repair works on the baths. Moreover, the repair works can last for as long as two years which for Peter will be a great loss. Peter argues that closing down the baths for two years will certainly deter tourists from visiting the town thereby leading to a decrease in the yearly income of his municipality.

After failing to reach any consensus with his brother, the doctor decides to inform the general public through the local newspaper, namely, The People's Daily Messenger. The newspaper men promise to stand by him in his fight for the truth that is badly needed for the cleansing of the society. The newspaper editor-in-chief, Hovstad reassures Doctor Stockman that the time has come for him to "break up that ring of pig-headed reactionaries who hold all the powers." Hovstad further states that he cannot let such a unique opportunity to sleep away. In his words, "the myth of the infallibility of the ruling class has to be shattered. It has to be rooted out, like any other superstition." (Act 2, 307). At first, everything seems to be in the doctor's favour. He naively thinks that with the journalists by his side, he is probably going to carry the day. But Peter Stockman, who doubles as Mayor and chairman of the board of directors in charge of water, does everything in his powers to frustrate all his plans.

After his unsuccessful attempt to get the support of the local newspaper men, Doctor Stockman plans to give a public lecture during which he will inform popular opinion or the entire community about his discovery at the baths. Nobody offers him a venue for the meeting excerpt his friend, the sea captain, Horster, who himself is less concerned with the daily affairs of the community. Most of his time is spent at the high sea at work. Although it is Dr Stockman who has taken the initiative to organize the meeting, newspaper publisher Aslaksen together with the masses mobilized by the Mayor take over control of the 
proceedings. Aslaksen is appointed as chairman of the meeting to stop Dr Stockman from saying anything about the town's baths. The doctor however struggles to utter a few incoherent statements in anger when he realizes that everybody is against him in the hall. After a protest and some disturbing noise from the crowd, the doctor continues:

Well my fellow citizens, I shall not speak more of our men

If anyone, of what I have just said, should imagine that I am

After their leading men's gut, then he is mistaken, very mistaken

Indeed, for I have the healing comfort that the parasites, all

Those old people of school of thought, they cause so excellently

Their own passing, there is no need for a doctor to hasten their

Departure. Nor is it people of that kind that are the most

Pressing danger, it is not they who are the most active in

Poisoning our immaterial sources of life and in infecting

The ground under us, it is not they who are the most dangerous

Enemies of truth and freedom in our society (Act 4: 530)

After listening to the doctor's cynical and distracted statements, the masses enjoin him to be more explicit by telling them who exactly "the most dangerous enemies are." The doctor further says:

Yes, you can be sure that I will name them, because that is exactly

The discovery I made yesterday. The most dangerous enemy of truth

Of freedom among us is the compact majority. Yes, the damned, Compact

Liberal majority-that is it, now you know it (Act 4: 530)

As soon as Doctor Stockman makes these statements, the crowd spearheaded by publisher Aslaksen utters cat-calls obliging the physician to withdraw his pronouncements. But the fearless doctor responds saying; "never Mr. Aslaksen, it is the great majority in our society that robs me of my freedom, and that wants to forbid me from telling the truth.

When Mayor Peter Stockman is given the floor, he, in a highly rhetorical speech attacks his brother, Doctor Stockman, for trying to tarnish the image of the town. He says that doctor Stockman "wants to prove that the administration blundered in constructing the springs." The politician further shamelessly states, like his counterpart, Consul Bernick in The Pillars of the Society that:

Now all you have got to ask yourself a simple question, has anyone

Of us the right, the democratic rights as they call it, to speak the

Minor flaws in the springs, to exaggerate the most picayune faults...

(Cries of no! no!) and to attempt to publish these defamations for

The whole world to see. We live and die on what the outside world
Thinks of us (Act 4: 536)

The mayor then goes ahead to enjoin his fellow countrymen to join forces with him and fight against what he calls "a common enemy." Doctor Stockman is unanimously declared "an enemy of the people." He is stoned and fired from his position of the town's baths physician. A campaign is launched for no one to use him as their personal doctor. His only friend, Captain Horster equally gets fired for letting the doctor use his residence for the meeting. Even the doctor's daughter who is a High School teacher is dismissed from work. The doctor's innocent children-Morten and Kill are also sent away from school for a few days. The fact that Morten and Kill are thrown out of school as a multiplier effect of their father's unwanted quest for truth, shows how even children's rights were violated in the hypocritical middle class Norwegian society by the conservative party men in power.

Note should be taken here of Ibsen's realistic use of political discourse as seen in the utterances of Mayor Peter Stockman. His language is reminiscent of that of conservative platform politicians who say one thing and mean another. He talks of the citizen's "democratic rights" to freedom of speech when in essence, he is interested in stopping Doctor Stockman from speaking the truth in public. He deprives his brother of the democratic right of freedom of speech. Peter is bent on putting up window dressing for "the outside world" to see. "Minor flaws in the springs" must be covered up in order not to scare potential customers away.

Ibsen shows his indignation against the democratic principle of majority rule in the words of Doctor Stockman when he says:

I am against the age old lie that the majority is always right...the

Majority never has truth on its side-I say. This is one of these societies

Lies that a free thinking man must revolt against... well, well, you can

Shout me down, but you cannot reply. The majority has might on its

Side-sadly, but it is not in the right. I and the other few individuals are

In the right (Act 4: 532)

The doctor further adds that "the majority is never right until it does right." Doctor Stockman is convinced that what he is saying is the truth, no matter the general outcry against him by the manipulated and ignorant masses. He is sincere in his convictions and stands by them against all odds. Democracy is projected here as the dictatorship of the majority. Ibsen's message in An Enemy of the People is that democracy hardly considers the opinion of the individual so long as the majority always carries the day through vote. This unfortunately means that even if an individual has all it takes to rescue a situation from getting worst as it is the case with doctor Stockman in the play at issue, he may never be given the opportunity or listened to since the democratic majority will always have a crushing effect on "he who stands most alone" This is exactly the fate that befalls doctor Stockman in 
An Enemy of the People. Under the corrupting influence of the all-powerful Mayor, Doctor Stockman is ironically rejected and stigmatized by all the members of the community whose welfare he struggles to protect. This is the sad reality we all notice around our contemporary societies wherein the good intensions of some members of the civil society are often frustrated by politicians in the so-called majority democratic political parties. The playwright is often quoted to have said, "I do not believe in political measures nor have much confidence in the altruism and good will of those in power."

\section{Socio-Economic Corruption and the Individual}

Another middle class conservative and influential personality who, like Peter Stockman in An Enemy of the People, mismanages democratic principles of good governance and respect for human rights is consul Bernick in The Pillars of Society. Bernick is the leading politician and financial magnet of the town. His family is regarded as that of the Rosmers in Rosmersholm, as the model in the community. Bernick is a capitalist who sacrifices everything for his economic purposes. Ibsen, like Karl Marx, was an enemy of capitalism because of its exploitation of the masses. While agreeing with Marx that capitalism worked to the detriment of the workers, Ibsen unlike Marx did not advocate class war wherein labourers unite and through a violent revolt, overthrow their masters. What Ibsen seems to suggest in his plays is mutual dialogue between the master and workers in finding solutions to common problems.

Ibsen however makes clear his hatred for capitalism in the hypocritical and corrupt commercial practices of Consul Bernick and his colleagues in The Pillars of Society. Bernick and his local business partners like Rumel, Vigeland and Sandstad are generally regarded as pillars on which the society stands for its welfare. Consul Bernick, for instance, co-runs a shipyard with American capitalists and they care very little about the welfare of workers. In Act two, the Consul quarrels with Aune, the Shipwright simply because the latter is unwilling to repair "The Indian Girl," a ship owned by the Americans with whom he manages the shipyard. He fears being blamed by his foreign counterparts. $\mathrm{He}$ is interested in protecting his public image especially in the eyes of his foreign partners. Local capitalists like Bernick exploit their fellow countrymen in order to satisfy their foreign business partners.

The Consul quarrels with the shipwright for the second time on issues related to the arbitrary replacement of workers with new machines.

Bernick-Yes, for your own limited circles for the working class. Oh I know all about your political agitations. You make speeches, you stir people up. But when a chance for tangible progress turns up as now with the machines, you won't collaborate. You are afraid.

Aune-Yes I am certainly afraid Bernick, I am afraid for all the people machines rob of their bread. You often speak sir, of considering the community, but I think that community has its inventions to work before the community has educated a generation that can use them.

Bernick-You read and think too much Aune. You get no good from it. That is what makes you discontented with your position.

Aune-It is not that sir, but I cannot bear to see one man after another discharged and losing his livelihood because of these machines (Act 3, 56)

This dialogue demonstrates that capitalists like Bernick do not take into consideration the negative effects of the introduction of machines on the individual worker. All they see is the benefit that will accrue from such ventures. Bernick is a capitalist who uses rhetorics to keep workers subservient to him. He blames Aune for reading too much, stating that he gets no good from such intellectual activity. He will want Aune to remain blind and humble about his secondary position in the shipyard so that he can continue to exploit him. Bernick like Mayor Peter Stockman in An Enemy of the People tells the shipwright that the individual must always be ready to subject himself to the community or morality:

Well, if nothing else can be done, the lesser must give way to the

Greater, when all is said, the individual must be sacrificed to the

Majority. That is the only answer I can give you, and that is the way

Things work in this world. But you cannot do anything else, but

Because you don't want to prove the superiority of machines over

Hand work. (Act 1, 58)

Consul Bernick, as a matter of fact, sacrifices his love, family and self to his commercial aim. The individual, he says, must be ready to sacrifice himself to the maximization of profit. Bernick discharges his workers indiscriminately without providing them with any alternative means for the sustenance of a livelihood. Capitalists like Bernick therefore abuse the democratic natural rights of their workers to share in the work which makes wise use of the earth's material resources. By dismissing them from work indiscriminately, Bernick leaves them with no other means to support themselves and their immediate families.

Nil Krogstad in A Doll's House is yet another middle class government official whose corrupt practices have a negative effect on the welfare of the other individuals. Kogstad in the play doubles as a banker and lawyer. Through him, Ibsen satirizes professional lawyers who instead of promoting justice in the democratic society in which they live, are ironically the first to go against the law. Doctor Rank describes Krogstad as "a moral invalid." Talking to Kristine about Krogstad, he says:

I don't know if you have in your neck of the wood a type of person

Who scuttles about breathlessly sniffing out hints of moral corruption? 


\begin{abstract}
And then maneuvers his victims into some sort of key positions where
\end{abstract}

He can keep an eye on him. It is the healthy that are in the cold these

Days in society (Act, 2, 467)

This excerpt is a clear indication of the fact that Ibsen is a socio-realistic writer who devotes his art to the criticism of contemporary societal vices. Krogstad is a state agent whose character, as doctor Rank puts it, "is rotten to the root." His corrupt practices are reminiscent of twenty-first century societies wherein people who occupy privileged positions more often than not manipulate the administrative machinery so as to procure lucrative positions or jobs for their family members and friends even if they have no qualification for the jobs. After securing such unmerited positions for the unqualified and incompetent relatives, the God fathers keep watch over their submissive servants in matters of remuneration. Here as highlighted earlier in this paper, the freedom of the individual is infringed upon. Those Krogstad manipulates into key positions are obliged to work following his dictates given that any deviation from his directives may cost such individuals their undeserved jobs. Krogstad's corrupt practices are damaging because no society can progress if those who possess the qualities, qualifications and potentials to work are left "in the cold" whereas the unskilled and unqualified ones are given pride of place. This is unfortunately the sad reality of many modern societies wherein gaining employment into certain public and private services, depends on who you know and which tribe or ethnic group you come from. Such discriminatory practices work against the democratic principles of equality, justice and freedom of all human beings. That is, people no longer have trust in themselves thereby killing creativity and even confidence in their leaders who are often the first to violate with impunity the laws that are voted and promulgated.

\section{Conclusion}

We set out at the beginning of this inquiry to investigate the thesis that Ibsen was not completely against democracy as some of his renowned critics uphold. The playwright was rather only indignant about the poor application of democracy by those who ran the affairs of the state. Janet Garton (15) quotes Ibsen's letter of January $3^{\text {rd }} 1882$, to his friend George Brandes in which the playwright expressed his worry about the state of affairs back in his home country on the advent of democracy. He regretted the fact that democracy had done very little in the enhancement of the individual's freedom. Democracy as he observed was tailored to suit only "party line." The playwright noticed that his fellow countrymen were still largely "narrow-minded" at a time when democracy, the most popular form of government, had been introduced in their country. He was, as Edwin Sloson [16] puts it, "a disillusioned democrat" (253). He expected his native brothers and sisters to rise above their previous provincialism and move forward with the fast changing times.
Ibsen succinctly gives a positive view of democracy in the character of Rosmer in Rosmersholm. This is evident in the following conversation between Rosmer and doctor Kroll.

Dr Kroll-Rosmer, I will never get over this (looks sadly at him) oh! that even you could give yourself to the forces of decadence and corruption that are undermining our miserable country.

Rosmer-It is the forces of liberation, I want to give myself to.

Dr Kroll-Oh I know about that, which is what they call it, both the pied papers and the tools that get led astray. But do you really think there is any liberation to be found in the spiritual position that is filtering through our whole society.

Rosmer-I am committed to the spirit that destroys. Not to any faction. I want to bring together people from all sides. As many as I can reach, as honestly as I can. I want to live and use all my vital energies towards that one end, the creation of true democracy in this land

Dr Kroll-Don't we have democracy enough? For my part, I think we are still on our way down into the muck and mire, where only the lowest of low can thrive.

Rosmer-Exactly why I want democracy to assume its rightful role

Dr Kroll-What role?

Rosmer-To elevate all our people into noblemen.

Dr Kroll-Through what means?

Rosmer-By liberating their minds and tempering their wills

Dr Kroll-You are a dreamer, Rosmer. Will you liberate them and temper them? (Act, 1, 518-519)

The preceding dialogue clearly demonstrates that Ibsen was not completely against the democratic form of government as many of his critics argue. He was rather interested in castigating the shortfalls of egoistic politicians who failed to properly apply the human friendly principles of democracy which worked against the individual's quest for freedom and self-realization. The playwright did not only end at criticizing the short comings of those who wield political power, but he as well suggested what democratic leaders should do to make the most popular form of government in modern society, more workable. The great task for democracy Ibsen says in the words of Rosmer, is, "to elevate our people into noble men." It is only through great men and women who are endowed with the utmost reasonable freedom as individuals that the realization of the lofty principles of democracy is possible. By liberating people's minds from conventional practices and "tempering their wills," as Rosmer puts it, democracy will as well be liberated from petty party politics.

\section{References}

[1] Groden, Michael and Kreiswirth M, The John Hopskin Guide to Literary Theory. Baltimore. John Hopskins University Press. 1994.

[2] A Doll's House, ed. Simon, Stephens, New York. Bloombury Publishing House, 2014. 
[3] Pillars of the Society in Ibsen: The Complete Major Prose plays, Trans. Rolf Fjelde. New York. The American Library Inc, 1978.

[4] An Enemy of the People, in Ibsen Plays: Two, A Doll's House, An Enemy of the People and Hedda Gabler, Trans, Michael Meyer, New York, 2014.

[5] Rosmersholm, in Ibsen: The Complete Major Prose plays, Trans. Rolf Fjelde, New York. The American Library Inc. 1978.

[6] Bassioni Cherif et al, Democracy: Its Principles and Achievement, Geneva. Inter-Parliamentary Union, 1998.

[7] Sama Albert, Nation Building: Good Governance and Human Rights. Yaoundé. Wisdom House Publishers, 2010.

[8] Roshwald Modecia, "The Alienated Moralist in An Enemy of the People," in The Modern Age, Vol. 46, London. Routledge, 2004, Pp 225-236.

[9] G K Chesterton, "A Handful of Author: Essay on Books and Writers" Twentieth Century Literaray Criticism. Bryfonski D and Sharon K, New Jersey. Gale Research Co. 1978, 221-222.

[10] Baltzersen K "Henrik Ibsen: Anti-Democrat and
Individualist", http//wwwlewrockwellcom:balzersen:clhtm Pp 2006, 1-17.

[11] Shaw Bernard, The Quintessence of Ibsenism, London. Constable and Company Ltd. 1972.

[12] Esslin, Martin, "Ibsen: An Enemy of the People, Hedda Gabler, The Master Builder, Twentieth Century Literary Criticism eds. Bryfonski D and Sharon K, New Jersey, Gale Research Co 1978, Pp 237-238.

[13] Mbeng A Didachos, "Artistic Complexities and Political Alternatives in Selected works of Henrik Ibsen", Unpublished Master Dissertation, University of Yaounde 1, 2010.

[14] Bloom Harold, Comprehensive Research and Study Guide, Bloom's Major Dramatists, London. Chelsea Publishing House, 2002.

[15] Garton Janet, "The Middle plays", in The Cambridge Companion to Ibsen. Ed. James Mcfarlane, Cambridge. Cambridge University Press. 1994 Pp 106-226.

[16] Sloson Edwin "Ibsen as an Interpreter of American Life"in Ibsen: The Critical Heritage, ed. Michael Egan, London. Routeledge and Kegan Paul, 1972, Pp 451-453. 